\title{
Freedom or Restraint: Redefining the Concept of Human Security within the Indonesian Muslim Community
}

\author{
Erwin Nur Rif' ah, University of Jember, Indonesia
}

\begin{abstract}
This study aims to explore the changing concept of human security in Indonesia. It concentrates on how Indonesian Muslims define human security based on their experiences and opinions relative to the definition of human security provided by the Commission on Human Security. This study focuses on two districts: Cianjur, West Java, and Bulukumba, South Sulawesi, where a form of Sharia law has been implemented. This research emphasizes the interplay between human security and women's security and the changing religious, social and political atmosphere relative to the implementation of Perda Sharia (Sharia-influenced regional regulations). Human security, as used in this paper and in keeping with the concept used by the UN Commission of Human Security's (CHS), refers the protecting fundamental freedoms; 'freedom from want, freedom from fear, and freedom to take action on one's own behalf.' This study found that, although there has been some discussion regarding the security of women during the implementation of Perda Sharia, widespread discussion and discourse on the concept of human security and women's security has remained unpopular in Indonesia. Surprisingly, it seems that the prevailing opinion among the populations of regions included in this study is that freedom is a western concept, has negative connotations, and is contrary to Islamic teachings and Indonesian culture. And, the informants argued that they did not seek 'freedom,' but rather sought 'restraint.'
\end{abstract}

Keywords: Human Security; Women's Security; Serda Sharia; Freedom; Restraint.

\section{INTRODUCTION}

Indonesia has the world's largest Muslim population, however, it has never been led by a government which supports the establishment of an Islamic constitution. Since Indonesia's independence, all efforts to establish an Islamic state in Indonesia have failed. However, after the fall of Suharto in 1998, and particularly after the Habibie government passed two laws which allowed for greater regional autonomy, many districts implemented Sharia-influenced regional regulations. By definition, Shariainfluenced regional regulations, or Perda Sharia, are additions to the legal system created by district governments which are derived from Islamic moral teachings. In general, Perda Sharia seeks to address and manage three aspects of public life: the 
eradication of moral and social 'ills' such as prostitution, drinking, and gambling; ${ }^{1}$ the enforcement of ritual observances among Muslims, such as reading the Qur'an, attending Friday prayer, and fasting during Ramadan; and the regulation of dress in the public places, and especially the head-veiling of women. ${ }^{2}$

The primary objective of regional autonomy is to give regions more authority and resources to manage their own development and affairs. ${ }^{3}$ Through Regional Autonomy Laws No. 22/1999 and 25/1999, which were implemented in 2001, district (kabupaten) and municipal (kota) governments have been given more power to unilaterally make decisions regarding how best to manage their regions, and to establish a democratic system which increase the participation of citizens, including women, in improving social welfare. ${ }^{4}$ From 2001 until the end of 2009, 154 regional regulations that reference Islamic moral teaching were implemented, and most of which were structured specifically to restricted women's rights ${ }^{5}$. By the end of 2010 , the number of such discriminatory regulations had increased to 189; in 2012, the National Commission of Women's Protection (Komnas Perempuan) noted that there were $282^{6}$ regional regulations which discriminated against women, a number which increased to 342 regulation in $2013 .^{7}$ Additionally, Lindsey observed that in 2007 around $70^{8}$ regions had

1 Laws against prostitution, gambling and consumption of alcohol operate in many legal systems and are not particular to Islam. However, the implementation of these Perda is different because the regulations are made based on religious motivation and using religious justification to express the religiosity.

2 R Bush, "'Regional Sharia Regulations in Indonesia: Anomaly or Symptom?" in Expressing Islam Relig Life Polit Indones (Institute of Southeast Asian Studies, 2008) 174; Dewi Candraningrum, Perda sharia and the Indonesian women's critical perspectives (Bremen, Germany, 2006); Arskal Salim \& Azyumardi Azra, Shari'a and Politics in Modern Indonesia, ISEAS series on Islam (Singapore: Institute of Southeast Asian Studies, 2003).

3 Maribeth Erb, Carol Faucher \& Priyambudi Sulistiyanto, Regionalism in Post-Suharto Indonesia (Routledge, 2013).

4 SM Mulia, "Syari'at Islam Tidak Mungkin Merendahkan Perempuan", (2001), online: Swara Rahima <http://www.rahima.or.id/SR/02-01/Opini.htm\%3E>.

5 In 2008 the government passed the pornography law which also discriminated against and violated women's rights. However, this issue is not discussed in this thesis due to the fact that the Pornography Law was not related to regional autonomy. The pornography law was also not associated with the issue of perda sharia, because the law was not enacted by any regional government but rather the central government. In addition, the Pornography Law was not developed in the framework of sharia, thus the proponents of the pornography law were not discussed in the context of support for sharia implementation. See Asmaul Khusnaeny et al, Tak Hanya di Rumah: Pengalaman Perempuan akan Kekerasan di Pusaran Relasi Kekuasaan yang Timpang (Komisi Nasional Anti Kekerasan Terhadap Perempuan, 2009).

6 Not all these discriminatory regulations were Perda Sharia. According to the Head of Komnas Perempuan, Yuniyanti Chuzaifah, from 282 regulations, 207 directly discriminate against women, 60 obligate women to wear Muslim clothes (long sleeves and skirt with a head-veil), 96 crimininalise women through anti-prostitution and pornography regulations, and 38 restrict women by limiting their work hours (jam malam), see Komnas Perempuan, "Komnas Perempuan: Ada 342 Perda Diskriminatif di Indonesia”, (2013), online: VOA Indones <https://www.voaindonesia.com/a/komnasperempuan-ada-342-perda-diskriminatif-di-indonesia/1736465.html>..

7 K Tri \& A Haksoro, "Indonesia Merdeka? Pemerintah Terbitkan 282 Perda Diskriminatif", (2012), online: <http://www.vhrmedia.com/2010/detail.php?.e=5927\%3E〉. 
Freedom or Restrain: Redefining the Concept of Human Security within the Indonesian Muslim Community

introduced Sharia-influenced regional regulations which force women to dress in a certain fashion and prevent them from going out at night. ${ }^{9}$ By 2009 the number had increased to 81 regions.

During the implementation of Perda Sharia, district police detained many women on the grounds that they had broken regional laws. For instance, in Tangerang City, which implemented Regional Regulation No. 8/2005 (a ban on prostitution), the police apprehended 11 women who were suspected of being prostitutes because they waited for a bus at a bus station after $8 \mathrm{pm}$. Other incidents involved women apprehended for drinking tea in small cafes, as well as one women who was accused for staying in a hotel alone while her husband went out to buy food. ${ }^{10}$ There has been no systematic collection of data regarding the number of detentions and arrests made under Perda Sharia.

The rise of regional Perda Sharia laws has resulted in considerably public discussion about human security and women's security within the Islam community and in Indonesia in general. During the implementation of Perda Sharia, there has been much debate about whether such regulations could actually enhance women's rights and women's security. Supporters of Perda Sharia argue that it will make women feel more secure, ${ }^{11}$ thus enhancing women's rights and security, whereas opponents argue that Perda Sharia will, in fact, jeopardise women's security and diminish their rights.

This paper explores the changing concept and perception of human security in Indonesia. It concentrates on how Indonesian Muslims, and especially women, define the concept of Human Security, as defined by the UN Commission of Human Security, based on their experiences and opinions. This study focuses on two districts: Cianjur, West Java, and Bulukumba, South Sulawesi, where a form of Perda Sharia law has been implemented. This research emphasizes the interplay between human security and women's security and the changing religious, social and political atmosphere relative to the implementation of Perda Sharia.

\section{WHAT IS HUMAN SECURITY?}

The global discourse over human security has developed since 1994, when the UN first published the Human Development Report. This report first outlined human security as a concept, and since then the idea of human security has begun to attract attention from academia and government officials. The central idea of human security, that people

8 The regions include Cianjur, Tasikmalaya, Indramayu, Bandung, Garut, Sukabumi, Depok, Majalengka, Karawang, West Java; Tangerang, Serang, Banten; Padang, solok, Bukit Tinggi, Sawahlunto, Agam, Padang Pariaman, West Sumatra; Bulukumba, Makassar, Gowa, Maros, Enrekang, Pangkep, Sinjai, Takalar, South Sulawesi; Banjarmasin, South Kalimantan; Gorontalo; East Lombok, Bima, Dompu, NTB; Pamekasan, Sumenep, East Java.

9 Tim Lindsey, Islam and Sharia in Today's Indonesia (Melbourne: The University of Melbourne, 2007).

10 S Soekirno, "Hati-hati minum di jalan, bisa ditangkap...", (2006), online: <http://www.kompas.com/kompas-cetak/0603/02/utama/2478744.htm\%3E〉.

11 The meaning of secure has become key, both as an issue and as a discourse, and it will be a focus of the discussion throughout this thesis. 
should have 'freedom from fear and freedom from wants,' has become rather popular. Human security refers to a kind of security that does not focus on so called 'traditional security,' which is concerned with the entity of the state. Instead, human security, as the name implies, focuses on the importance of protecting the well-being of the human race, not just the security of one's own people, and transcends distinctions between people based on nationality, ethnicity, class, culture, gender, and religion. The UN stated that human security covers seven dimensions of security and well-being that are necessary to ensure these freedoms. These seven dimensions are: economic (threats include unemployment, job insecurity, income inequality, poverty and homelessness), food (including inadequacy of food available, and food entitlements), health (such as infectious diseases, new viruses, parasitic diseases and respiratory infections), environmental (degradation of air, water, soil and forest), personal (including discrimination, exploitation, crimes and terrorism), community (ethics and communal conflicts) and political (violation of human rights). ${ }^{12}$

In 1999, the Human Security Network (HSN) was formed. The aim of the HSN is '...to energize political process[es] aimed at preventing or solving conflicts and promoting peace and development.' This shift in paradigm, from protecting the state to protecting the people, continues to invite debate among scholars. By focusing on people, human security does not mean that it completely excludes the state, as many human security issues require state action, and in some cases a cessation of action, as well as a serious commitment by states to protect their people.

In 2000 the Commission of Human Security was established at the UN Millennium Summit. The aim of this commission is to address critical and pervasive threats to human security. In 2003, the Commission of Human Security submitted the report, 'Human Security Now', which further expanded the definition of human security to include:

...protecting people from critical and pervasive threats and situations, building on their strengths and aspirations. It also means creating systems that give people the building blocks of survival, dignity and livelihood. Human security connects different types of freedoms: freedom from want, freedom from fear and freedom to take action on one's own behalf. To do this, it offers two general strategies: protection and empowerment. ${ }^{13}$

However, this definition has been criticized by some scholars, particularly those concerned with women's issues, over concerns as to whether this definition adequately covers women's security. ${ }^{14}$

12 UNDP, "Reports | Human Development Reports", online:

<http:/hdr.undp.org/en/reports/global/hdr1994/http:/hdr.undp.org/en/\%20reports\%20/global/hdr1994/ch apters $\% 3 \mathrm{E}>$.

13 CHS, "Human Security Now", (2003), online: Comm Hum Secur 〈http://ochaonline.un.org/humansecurity/CHS/finalreport/index.html\%3E〉.

14 C Bunch, "A feminist human rights lens" (2004) 16:1 Peace Rev 29; M Caprioli, "Democracy and Human rights versus Women's security: a contradiction?” (2004) 35:41 Secur Dialogue 411; Anuradha Chenoy, "A plea for engendering Human security” (2005) 42:2 Int Stud; G Hoogensen \& SV Rottem, "Gender identity and the subject of security" (2004) 35:2 Secur Dialogue 155; Heidi Hudson, "Doing' 
Freedom or Restrain: Redefining the Concept of Human Security within the Indonesian Muslim Community

Furthermore, Tadjbakhsh and Chenoy explained that the concepts of 'security' and 'insecurity' have different meanings in different contexts. ${ }^{15}$ For some, insecurity comes from a sudden loss of a guarantee of access to jobs, health care, social welfare and education. For others, it stems from a violation of human rights, extremism, domestic violence, the spread of conflicts, and displacement. Therefore, to be meaningful, security needs to be redefined as a subjective experience at the micro level in terms of people's experiences.

The Commission on Human Security defined human security as: 'the protection of the vital core of all human lives in ways that improve human freedom and human fulfilment.' ${ }^{16}$ According to Truong, Wieringa, and Chhachhi, discourses on human security have brought together the issues of human dignity, human rights, and wellbeing in a comprehensive way. ${ }^{17}$ Human security connects different types of freedoms, such as the freedom from want, the freedom from fear, and the freedom to take action on one's own behalf. To do this, the concept includes two general strategies: protection and empowerment. Protection shields people from dangers, are it requires a concerted effort to develop norms, processes, and institutions that systematically address insecurities. Empowerment enables people to develop their potential and become full participants in decision-making processes. ${ }^{18}$ However, the discourse over human security is always followed by two questions: 'Does the human security concept show equal concern for women? Is women's security ensured under the human security concept?' 19

In many works published on human security, scholars have tried to connect women's security to human security. ${ }^{20}$ In general, human security can enhance gender justice because human security approaches and methods attempt to overcome physical and structural violence ${ }^{21}$, which contributes to the domination of men over women. ${ }^{22}$ Furthermore, diverging from the concept of traditional security, the concept of human security, according to Bunch, will assist in bringing to light the multiple factors that influence women's lives, of which perhaps the most pressing are the threat of violence in their daily lives and the lack of control over reproduction. ${ }^{23}$ According to Chenoy, 'women's insecurity can come from within the family, from community conflict or from

Security as Though Humans Matter: A Feminist Perspective on Gender and the Politics of Human Security" (2005) 36:2 Secur Dialogue 155.

15 Shahrbanou Tadjbakhsh \& Anuradha Chenoy, Human Security: Concepts and implications (Routledge, 2007).

16 CHS, supra note 13.

17 Thanh-Đạm Trương, Saskia Wieringa \& Amrita Chhachhi, Engendering human security: feminist perspectives (Zed Books, 2006).

18 CHS, supra note 13.

19 Chenoy, supra note 14.

20 Caprioli, supra note 14; Chenoy, supra note 14; Susan McKay, "Women, Human Security, and Peacebuilding: A Feminist Analysis” (2004) 19 IPSHU Engl Res Rep Ser 152.

21 Structural violence refers to a form of violence wherein some social structure or social institution may harm people by preventing them from meeting their basic needs (Johan Galtung, 1969).

22 Abubakar E Hara, Promoting women security as human security: Indonesian women attempt to find their place in the newly Indonesia democracy' (Bangkok, 2007).

23 Bunch, supra note 14. 
state or interstate sources. ${ }^{24}$ The insecurity is largely invisible in the private sphere and gendered in the public sphere'. ${ }^{25}$ Additionally, some researchers found that 'women's security is systematically violated in both the public and private spheres, and that legal equality in the public sphere cannot lead to women's security without equality in the private sphere'. ${ }^{26}$

\section{HUMAN SECURITY IN INDONESIA}

The discussion over human security and women's security is relatively new to Indonesia. These issues have become more sensitive after many districts implemented forms of Perda Sharia law which regulate women's dress and behaviour. During the introduction of Perda Sharia, very often women's attire and security has been the major topic of debate. Some supporters of Perda Sharia argue that such regulations enhance women's security, whereas opponents argue that Perda Sharia creates discrimination against women, restricts their freedom and therefore threatens their security.

Perda Sharia has been introduced in Muslim-majority areas which nonetheless possess a significant population of Christians and other minorities. However, in such cases the right to religious freedom has been guaranteed and respected. Community members have been very tolerant of existing religious differences. Although freedom of religious practice has been rarely mentioned in reports over the efficacy of Perda Sharia, some non-Muslim contributors have stated that the implementation of Perda Sharia has not affected their religious freedom. However, the implementation of Perda Sharia has increased the number of women wearing a jilbab and this made wearing non-Muslim clothing more conspicuous.

The implementation of Perda sharia has become the concern of Christians, however they have to conform the implementation of Perda Sharia as it has, for the most part, only applied to Muslims. Some complaints and objections have arisen regarding the ineffectiveness of Perda Sharia; alcohol consumption is still common, although it is restricted under the Sharia regulations. The pressure to wear the jilbab has also been greater than expected. As one member of a community which has implemented Perda Sharia noted:

During the celebration of Indonesian Independence there was marching and the people who joined the marching had to wear jilbab, no matter they were Chinese or Christian, including my daughter she had to wear jilbab (although she is Christian)...for Toraja women, veiling (covering their head) is a sign for condolence $^{27}$...it was a bit silly as the marching [by wearing head-veil] was not religious activity but rather sport (Lewis, government staff, Bulukumba).

\footnotetext{
24 Chenoy, supra note 14.

Ibid.

26 Caprioli, supra note 14.

27 The Toraja women usually wear head cover called passapu during funeral ceremonies.
} 
Freedom or Restrain: Redefining the Concept of Human Security within the Indonesian Muslim Community

During the interviews, Christians did not mention discrimination overtly, and did not admit to experiencing it. However, one could form the impression that they had been subject to intimidation, harassment and discrimination. As one Christian said:

We have never experienced intimidation... [however] many people did not know the regulation [that there are exceptions for non-Muslim], thus government staff who were Christian and Chinese, including my daughter have always been reprimanded for not wearing jilbab. However, after they know that she is my daughter, she has never been reprimanded anymore (Lewis, government staff, Bulukumba).

Christians are a minority in the community of Bulukumba, with only about 50 households, and 200 members. Although Christians are subjected to unpleasant treatment, they relent and conform because of their minority status. They want to maintain a balance of tolerance and social harmony. Therefore, they accept Perda Sharia in order to gain security as a minority group. Furthermore, some female government staffers who are Muslim but do not regularly wear jilbab, comply with the regulation by wearing jilbab during work hours. They remove jilbab after work, and accept the Perda Sharia simply to maintain their job security.

\section{HUMAN SECURITY OR SECURING MORALITY}

One objective of Perda Sharia is the strengthening of community morality; this has serious implications regarding women's security. The differing definitions of security obviously depend upon who possesses the political resources and power to control women's lives. In a patriarchal society such as Indonesia, men occupy a much stronger position and possess much more power than women. As Hara has stated, many policies have been based on 'masculinist-dominant' discourses. ${ }^{28}$ These discourses have helped to maintain the status quo of gender related human insecurity in Indonesia. In the districts where the men dominate the local parliament, regional regulations are based on male perceptions and beliefs about women. For example, security is often defined to include security from 'immoral activities.' In turn, these 'immoral activities' are defined as being caused and initiated by women's behaviour and fashion. Therefore, according to this masculinist perspective, moral regulations should control women's behaviour and dress, and encourage women to be sholehah, or a 'good woman'. In keeping with this mindset, male-dominated parliaments in some districts have produced regulations that oblige women to wear a jilbab, or impose night-time curfews for women. There is also often an implied threat that women who do not conform with these regulations will be denied 'security' and will be considered to have bad morals. These assumptions are related to the Hadith, a section in the Alqur'an, which are often interpreted under the influence of traditional patriarchal values. As Kyai Halim, an Islamic scholar and head of the $\mathrm{MUI}^{29}$ in Cianjur, states:

\footnotetext{
28 Hara, supra note 22.

29 MUI is acronym of Majelis Ulama Indonesia (Indonesian Council of Ulama)
} 
In the Hadith, it is clearly stated,'The most devout people are the people who respect the women". And the regulation about jilbab is aimed to respect women...veiled women is a good sign and it means good women [sholehah] (Kyai Halim, the Head of MUI Cianjur, interviewed 02 February 2008).

Most respondents, including women, expressed the belief that by displaying moral behavior they would be granted greater respect within their communities, and therefore be safe from assault andharassment, and feel more secure. Yet the moral standards they are expected to uphold are based on a 'masculinist-dominant' tradition which has been passed down from generation to generation, and which is now common-practice throughout Indonesia. And the practices are reinforced by the implementation of Perda Sharia. So, it is not surprising that people's understanding and opinions are strongly influenced by the patriarchal view and support the view. Below a male religious leader, Kyai Choirul, explains the 'need' for patriarchal moral standards:

Do not blame men if women were insulted or harassed, yeah... it is because women who invite those acts by not covering her whole body (pakaiannya buka-bukaan)... it attracts the sexual arousal of men (Kyai Choirul, interviewed 13 February 2008).

This happens because the formal interpretation of Sharia has shown that in a society characterised by patriarchal structures, Islamic Law is used to regulate and control the behavior and outward symbols of women. Furthermore, Yayuk, a member of the Democratic Party (Partai Demokrat-PD) in Cianjur stated:

Being secure is when we can protect ourselves by dressing modestly; cover our body properly, so it will not invite other people to act impolitely to us (Yayuk, Cianjur, interviewed 09 May 2008).

As one would expect given this belief, after incidents of harassment or assault, women are not considered to be the victims, but are blamed for causing immoral and criminal acts. Unfortunately, this patriarchal moral standard is believed and upheld by both men and women alike.

This perception of femininity and sexuality assumes that women will experience sexual harassment or even rape if they show certain parts of their bodies. Therefore, for the sake of women's own security, regulations are enacted that define women's bodies and their sexuality as dangerous, and as something that needs to be 'secured' (covered). Of course, this idea works against the fact that women's bodies belong to the women themselves, and that they should have rights to decide what to do with their own bodies. $^{30}$

Female morality, therefore, has become a core concern of both community and the state; security depends upon women's moral attitude. Women have a responsibility to maintain morality by monitoring and regulating their own dress and behavior, because

30 Women Research Institute, "Potret Perempuan dalam Era Otonomi Daerah - Women Research Institute", (2007), online: Women Res Inst <http://wri.or.id/172-current-project-id/perempuanpolitik/partisipasi-perempuan/54-potret-perempuan-dalam-era-otonomi-daerah\#.WnGXVqiWaUk>. 
Freedom or Restrain: Redefining the Concept of Human Security within the Indonesian Muslim Community

a woman's behavior reflects upon the community's and the state's identity and morality. As Kyai Tjamiruddin, the Head of MUI in Bulukumba states:

The pillar of the state is women who have good morals (perempuan sholehah) who are able to teach their kids in a good way. If the kids have good morals, it means the next generation of our state will be good, hence, our country and state will be good, strong and secure (Kyai Tjamiruddin, interviewed 07 June 2008).

A moral woman is a woman who wears the jilbab and other Muslimah clothes, stays at home to care for her husband and children, and is able to educate the children and manage the home. Some female respondents also expressed the opinion that a good woman should not abandon her responsibilities at home, even if she worked and had a prominent career outside the house (Yayuk, a homemaker, Bulukumba, interviewed 21 July 2008; Diana, female government staff, Cianjur, interviewed 08 April 2008; Yani, Political Party activist, Cianjur, interviewed, 12 March 2008). This moral standard is common to both the Cianjur and Bulukumba districts, and is widely upheld practiced in the community.

Some women believed that wearing the jilbab shows greater adherence to religious teachings: a woman who wears the jilbab is a better Muslim than one who does not. Therefore, it is unsurprising that many women express the opinion that they feel more secure and respected when wearing a jilbab. One female informant said:

If we want to be secure, we have to refer to Islam and respect the local culture/custom... we are bound by our belief. We have customs, have ethics, a norm, so we are very grateful living in Islamic country, unlike others (Yayuk, female, Cianjur, interviewed 21 June 2008).

Women in these communities conform to fulfil community expectations and religious obligations, and thereby gain greater security. However, many disagreed with the assertion that the regulations forced them to wear the jilbab. According to them, a woman decides whether or not she wants to wear jilbab; it is a person matter. In this way, they argue, women have authority and autonomy in decision-making, and so experience greater security. However, they have to accept the regulation as it has been implemented, thus, they conform it.

Surprisingly, the majority of female respondents accepted the implementation of Perda Sharia, despite the inclusion of regulations obliging them to wear the jilbab, and restricting their freedoms to some extent. They believe that wearing the jilbab is a religious obligation, and the government regulation on veiling (Perda Sharia) is in accordance with their religious beliefs. People comply these regulations because they believe the government has the authority and the right to 'improve' people by regulating morality. Furthermore, in the Cianjur district, acceptance of these laws was also motivated by the fact that Perda Sharia only obliged government staff to wear a jilbab during work hours. Thus, it was viewed as a sort of uniform. For women who do not occupy government positions, the regulation was treated as more of a suggestion. The Bulukumba district's Perda Keagamaan, by contrast, not only required government 
staff, but all women in the district to wear a jilbab. Some female respondents reported that they carry scarves in case of raids, and to always be prepared to go out in public.

Nevertheless, these respondents generally accepted the regulations, as they accepted the state's role in supporting Islamic values. During interviews, most female respondents said that they felt more secure since the implementation of Perda Sharia for a number of reasons. First, more people wear the jilbab and therefore act more 'religiously.' Here it is believed that greater religious conformity ensures a comfort and security within the community. Second, the regulations relating to women's dress do not prescribe a punishment for infractions (at least in the Cianjur district). Third, at the time interviews were conducted, the new regulations had been in place for more than three years, enforcement of the regulations had been lax, and there was a degree of flexibility over one's decision to wear the jilbab. As one female informant related:

The regulation was fully enforced immediately after it was implemented, but now is not anymore. Thus I feel more secure (Suryani, homemaker, Bulukumba).

This decrease in regulation-related raids and government pressure several years after Perda Sharia was first implemented led to feelings of greater security among the female respondents, especially for those who do not wear head-veil (jilbab) as regular clothes.

\section{ENHANCING SECURITY}

During the course of data collection, it became clear that different respondents use different strategies to improve their security. Conforming to and compromising with the regulations in order to gain security were common strategies. In this respect, women not only tried to conform to the regulations by wearing jilbab even when they didn't want to, but also by restricting themselves from going out from their homes at inappropriate times. They did this to avoid public shame and to avoid-breaking the government regulation, as explained by Wiwin, a homemaker from Cianjur:

I preferred to stay at home because the former Bupati often went to the streets and distributed jilbab to the unveiled women while speaking through a loud speaker to encourage women to wear veils, it made me ashamed (Wiwin, interviewed 14 March 2008).

Moreover, the influence of broader social pressures ensures women always try to conform to the regulations. Although there are no legal punishments for women who rejected the regulations, social pressure and community control are more powerful restraints.

Most of the female respondents accepted the implementation of Perda Sharia, as did the men. However, similar perceptions among woman concerning security, ensures the effectiveness of these regulations. In improving security within their districts, policy makers should listen to the voice of the population, and particularly to women, as women are the primary target of these policies. Women should be considered as active agents, concerned with their own problems and capable of knowing their own needs. Women should be the subjects, not the objects of the policy. A participatory approach 
Freedom or Restrain: Redefining the Concept of Human Security within the Indonesian Muslim Community

should be used to understand what women want regarding their security. Policy makers should understand that gender equality is a core component of human rights and that gender-based abuses are also human rights abuses. It must be acknowledged that significant difficulties exist in promoting greater gender equality and human rights in the two districts studied.

In these two districts where the research was conducted, some women complaining that their opinion and existence are ignored and their capabilities are not respected. Therefore, acknowledge Women's capabilities and listen women's voice are important in order to ensure security and respect. Such acknowledgment could come from the family members, or from the workplace. In Cianjur and Bulukumba, the implementation of Perda Sharia did not improve unequal power relations between men and women. Most policies were made by men, and ignored women's opinions and interests. This was admitted by a compiler of the strategic plan (Renstra) of Perda Sharia in Cianjur:

There are many women in high positions as government staff [and eligible to be involved in the regulation making process], but we simply forget to involve them in the decision-making process of Perda Sharia (Guguh, the compilers of Perda Sharia, Cianjur).

Giving women greater personal freedoms would be a powerful form of acknowledgment, and it would allow women to take responsibility and be accountable for their own actions. A female member of the DPRD explained that some of her colleagues, who are mostly male, underestimated her simply because she is a woman:

I feel secure when I am respected based on my capability, so far, women are always underestimated... As a member of parliament, sometimes, I feel threatened, especially because I am active and critical... You know, most leaders of the political parties are men, and they are worried if female (politicians) have strong influences in the community. They are worried if they will be defeated (in the election) by female candidates because women have the advantage of being closer to the community more easily (Titin, Member of Parliament Cianjur, interviewed 15 March 2008).

Some women have suggested that the government should only enact regulations aimed at ensuring women's security, such as the regulations concerning domestic violence, based on the women's perspective. To do this, the involvement of women in the political process is required. As explained earlier, the concept of human security, offers two general strategies: protection and empowerment. Protection shields people from dangers and requires a concerted effort to develop norms for its implementation, the creation of institutions that systematically address insecurities. Empowerment enables people to develop their potential and become full participants in decision-making. ${ }^{31}$

\section{WOMEN DEFINE WOMEN' S SECURITY: FROM FREEDOM TO RESTRAINT}

31 CHS, supra note 13. 
The implementation of Perda Sharia is good. It regulates the women how to behave and to be a good woman... thus women feel more secure and respected (Yayuk, a homemaker, ${ }^{32}$ Bulukumba, interview 21 July 2008).

There is no improvement (since the implementation of Perda Sharia) for the women's security... in fact that, it could jeopardise women's security, especially for women who are not wearing jilbab (Diana, female government staff, Cianjur, interview 8 April 2008).

The two quotes above illustrate the broad spectrum of women's opinions regarding their security and Perda Sharia. Among the women themselves, opinion regarding the implication of Perda Sharia ranged from general support to outright rejection. Women's differing experiences affect their perceptions of their security. In the districts where research was conducted, most of the respondents did not subscribe to any one particular concept of human security. Their understanding of (human) security mainly reflected notions of traditional security: freedom from conflict and violence, where 'peace means the absence of war' and 'security means absence of threats or communal conflict'. However, when they were introduced to the concept of human security according to CHS ('freedom from fear and freedom from wants'), most of the respondents argued that greater freedom would not guarantee women's security. ${ }^{33}$ As one female respondent from Cianjur said:

We cannot refer to the Western culture that has freedom, a freedom to do everything... So they are free to express but too far, so, I think it is not even safe...[we live in] this Islamic country with its rules, well we feel protected, that our community as it is... although other people [from other country] said that it is monotonous, but in terms of security, I think so secure (Yani, interviewed 14 March 2008).

The definition of security expressed by women is varied and mainly relates to their experiences, daily problems and needs as women. Yayuk, a homemaker from Bulukumba stated:

Being secure to me is when I have a harmonious family in which there is no conflict between a husband and a wife nor [between parents and] the kids as well as [between the family] and the community (Yayuk, interviewed 09 May 2008).

Most women considered the family as the core of their security concerns. To lend credence to this believe, it has been widely held that criminals come from disharmonious families. Economic security is also important, as insufficient finances might lead to family conflict, or even trigger criminal activity within the community. In

32 I intentionally use term homemaker, a gender-neutral term preferred to housewife.

33 CHS, supra note 13. 
Freedom or Restrain: Redefining the Concept of Human Security within the Indonesian Muslim Community

this way, security within a family influences security for the whole community (Yani, interviewed 27 July 2008). Therefore, women often maintain family harmony by sacrificing their own wants and wishes, and even allowing themselves to become victims of domestic violence. Bearing this in mind, the enforcement of regulations which protect women from domestic violence, such as the Against Domestic Violence Law (UU KDRT-Undang-Undang Kekerasan Dalam Rumah Tangga), is of paramount importance in order to ensure women's security inside their own families. Some informants also considered security as freedom, as narrated by a homemaker in, Cianjur:

I feel secure when my husband gives me freedom and does not easily suspect me, because if we get more freedom, we will be more responsible (Anita, a homemaker, Cianjur)

Freedom in this context is related to trust. trust is also vital to women' security. When women are trusted they will feel more secure. Additionally, the freedom to express themselves through fashion and dress is considered to be part of providing greater security. Some respondents explained that although they did not wear a jilbab, they knew how to behave in eastern cultures, and although not wearing a jilbab does not preclude moral behaviour, they are aware that this will result in more insults and even harassment. A female university student said:

I feel secure when I could walk and no one [boy] whistles or stares at me, even when I am wearing a skirt or tight pants and a short T-shirt (Ayu, Cianjur).

Thus, to avoid the public harrasment and to gain security the girl restrain herself and prefer to wear jilbab rather than wearing short pant.

In these two regions the term 'freedom' (kebebasan) and free (bebas) have negative connotations, and, according to some respondents are associated with western culture. The words 'free' and 'freedom' are components of the negative terms like sex bebas (free sex), budaya bebas (free culture), and pergaulan bebas (promiscuity). Therefore, women believe they have to limit their freedom and restrain themselves from wants. They must obey community norms by following religious and social rules, and respect the local culture. These women feel secure as long as they behave and dress in the manner in which their community expects them to. Greater freedom is incompatible with the local culture and traditional wisdom. In fact, during the interviews, some respondents used terms that refer to independence, self-determination, and autonomy, which have more positive connotations than 'freedom'. These terms express a freedom with limitations.

Therefore, each time respondents used the word freedom, they always emphasise an associated 'limit' (kebebasan yang terbatas). Apart from this, women think that if they are given freedom, to some extent they are being abandoned (dibiarkan, tidak dipedulikan). Therefore, since the CHS definition of human security emphasises freedom, in a way itis not fully applicable in the two districts studied, where women prefer to practice 'restraint' and 'self-control' in order to gain security. 
Discourse on human security is not common among the Indonesian public; even the government has failed to promote discourse on the subject, and lacks a proper understanding of it. Therefore, many regulations have been implemented that jeopardise both human and women's security. However, these regulations are confirmed and even wanted by the community. The western cultural context which has formed the background for the definition on human security developed by the Commission on Human Security, is at odds with local wisdom and local cultural values regarding women's experience. ${ }^{34}$ This seems to be particularly true in the districts where the research was conducted. It is not surprising, therefore, that most respondents disagreed with the concept of human and women's security as outlined by the CHS. Standards cannot be generalised, and traditional local beliefs must be respected. Therefore, understanding the traditional wisdom and cultural values is vital in order to conceptualise both human and women's security in a manner which makes them more easily adopted by that local communities in Indonesia.

\section{CONCLUSION}

In the districts where men dominate the district parliament and Perda sharia has been implemented, regional regulations are based on male perceptions about women, femininity, and sexuality. One objective of Perda Sharia is the enhancement of community morality; this has had implications regarding perceptions of women their security. For example, if security is defined as security from immoral activities, and if these immoral activities are defined as being caused or initiated by women's behaviours and dress, then according to this masculine-dominant perspective, moral regulations should control women's behaviour and how women should perform in to promote security. These beliefs are drawn from the Hadith, a section the Alqur'an, which has traditionally been interpreted from a patriarchal perspective. Patriarchal values have been internalized and embedded in women's minds. Thus, if an idea or act is not in line with patriarchal values, the community, and particularly women, will refuse to adopt or accept the idea or act, as patriarchal ideology has been embedded in the community. Following from this belief, women who do not conform to the new regulations will loose security and will be considered to be immoral. Therefore, many women in these districts understand that by displaying good morals they will be respected, will be safe from assault or harassment, and will feel more secure. It is difficult for women to be critical of Perda Sharia in public for fear of being labelled 'non-Islamic'.

Most of women do not agree to the concept of human security offered by UN Commission of Human Security. They belief that it is western concept and do not fit in with Indonesian culture. Freedom as a core meaning of human security mainly have negative connotation in these two districts. The definition of security used by women varies widely and covers a very broad area, including personal security, the community's security and the political security. Women defined security in relation to the fulfilment of their needs, such as the need to be respected and to feel comfortable, being trust, a sufficient household economy, the recognition of capability, the provision

34 Ibid. 
Freedom or Restrain: Redefining the Concept of Human Security within the Indonesian Muslim Community

of freedom with limitations, the ability to be responsible and accountable for their own actions.

\section{BIBLIOGRAPHY}

Bunch, C. “A feminist human rights lens” (2004) 16:1 Peace Rev 29.

Bush, R. "Regional Sharia Regulations in Indonesia: Anomaly or Symptom?" in Expressing Islam Relig Life Polit Indones (Institute of Southeast Asian Studies, 2008) 174.

Candraningrum, Dewi. Perda sharia and the Indonesian women's critical perspectives (Bremen, Germany, 2006).

Caprioli, M. "Democracy and Human rights versus Women's security: a contradiction?" (2004) 35:41 Secur Dialogue 411.

Chenoy, Anuradha. "A plea for engendering Human security" (2005) 42:2 Int Stud.

CHS. "Human Security Now", (2003), online: Comm Hum Secur <http://ochaonline.un.org/humansecurity/CHS/finalreport/index.html\%3E〉.

Erb, Maribeth, Carol Faucher \& Priyambudi Sulistiyanto. Regionalism in Post-Suharto Indonesia (Routledge, 2013).

Hara, Abubakar E. Promoting women security as human security: Indonesian women attempt to find their place in the newly Indonesia democracy' (Bangkok, 2007).

Hoogensen, G \& SV Rottem. "Gender identity and the subject of security" (2004) 35:2 Secur Dialogue 155.

Hudson, Heidi. “'Doing' Security as Though Humans Matter: A Feminist Perspective on Gender and the Politics of Human Security" (2005) 36:2 Secur Dialogue 155.

Khusnaeny, Asmaul et al. Tak Hanya di Rumah: Pengalaman Perempuan akan Kekerasan di Pusaran Relasi Kekuasaan yang Timpang (Komisi Nasional Anti Kekerasan Terhadap Perempuan, 2009).

Komnas Perempuan. "Komnas Perempuan: Ada 342 Perda Diskriminatif di Indonesia", (2013), online: VOA Indones <https://www.voaindonesia.com/a/komnas-perempuanada-342-perda-diskriminatif-di-indonesia/1736465.html>. 
Lindsey, Tim. Islam and Sharia in Today's Indonesia (Melbourne: The University of Melbourne, 2007).

McKay, Susan. "Women, Human Security, and Peace-building: A Feminist Analysis" (2004) 19 IPSHU Engl Res Rep Ser 152.

Mulia, SM. "Syari'at Islam Tidak Mungkin Merendahkan Perempuan”, (2001), online: Swara Rahima <http://www.rahima.or.id/SR/02-01/Opini.htm\%3E>.

Salim, Arskal \& Azyumardi Azra. Shari'a and Politics in Modern Indonesia, ISEAS series on Islam (Singapore: Institute of Southeast Asian Studies, 2003).

Soekirno, S. "Hati-hati minum di jalan, bisa ditangkap...", (2006), online: <http://www.kompas.com/kompas-cetak/0603/02/utama/2478744.htm\%3E〉.

Tadjbakhsh, Shahrbanou \& Anuradha Chenoy. Human Security: Concepts and implications (Routledge, 2007).

Tri, K \& A Haksoro. "Indonesia Merdeka? Pemerintah Terbitkan 282 Perda Diskriminatif", (2012), online: <http://www.vhrmedia.com/2010/detail.php?.e=5927\%3E>.

Trương, Thanh-Đạm, Saskia Wieringa \& Amrita Chhachhi. Engendering human security: feminist perspectives (Zed Books, 2006).

UNDP. "Reports | Human Development Reports", online: <http:/hdr.undp.org/en/reports/global/hdr1994/http://hdr.undp.org/en/\%20reports\%20 /global/hdr1994/chapters/\%3E >

Women Research Institute. "Potret Perempuan dalam Era Otonomi Daerah - Women Research Institute", (2007), online: Women Res Inst <http://wri.or.id/172-currentproject-id/perempuan-politik/partisipasi-perempuan/54-potret-perempuan-dalam-eraotonomi-daerah\#.WnGXVqiWaUk>.

Erwin Nur Rifah is currently a lecturer of Public Health at the Universitas Jember. After receiving her bachelor's degree majoring in International Relation at the Universitas Jember, in 2003 she granted a scholarship from Ford Foundation to study MA in Social and Behavioral Sciences at Universiteit van Amsterdam in the Netherlands, majoring in Medical Anthropology. In 2007 she was awarded Australian Leadership Award scholarship from Aus-Aid to study Ph.D. in Social Sciences and Psychology at Victoria University, Australia. Her thesis titled "Women Under Sharia: Case Studies in the Implementation of Sharia-Influenced Regional Regulations (Perda Sharia) in Indonesia". 